\title{
Role of Social Studies Education in National Development in Nigeria
}

\author{
Ahmad Abubakar \\ Department of Social Studies \\ Shehu Shagari College of Education, Sokoto-Nigeria
}

\section{Doi:10.5901/ajis.2013.v2n6p23}

\begin{abstract}
Social Studies Education as a field of study instills in students the knowledge, skills, attitudes and actions that are considered important in the relationship and interaction of man and those around him on one han, and the entire environment (Ogun Bameru, 2006). The paper examines social studies education in the context of Nigeria's philosophical goals as a nation, the objectives of social studies education and how they can be used to achieve national goals and development and proffers some suggestions which include public enlightenment and teaching basic tenets of social interaction among others.
\end{abstract}

\section{Introduction}

Social studies education as an area of study has alot of contributions towards the attainment of the national objectives. It involves the adult and the young within the society to develop their competencies to enable them solve and manage the socio- economic and physical forces arising in their midst. It is not concerned with either the study of men per say, rather with the study of man within the context of his environment, his social, physical, political, economic, cultural and technological environment. (Ezegbe, 1994).

\section{Social Studies Education and the Nigerian Philosophical Goals and Objectives}

The Nigeria educational system has undergone many changes in the last few years, and no doubt there will be many more changes by the end of the century. Since a National Policy on Education is government's way of achieving that part of its National Objectives that can be achieved using education as a tool, no policy on education can be formulated without first identifying the overall philosophy and objectives of the Nation.

\subsection{The Main National Objectives of Nigeria as stated in the National Policy on Education are:}

1. A free and democratic society,

2. A just and egalitarian society,

3. A United, strong and self reliant nation

4. A great and dynamic economy, and

5. A land of bright and full opportunities for all citizens.

2.2 The National Educational objectives to which are linked to philosophy are:

i. The inculcation of National Consciousness and national unity 
ii. The inculcation of the right type of values and attitudes for the survival of the individual and the Nigeria society.

iii. The training of mind in the understanding of the world around, and

iv. The acquisition of appropriate skills, abilities and competence both mental and physical as equipment for the individual to live in and contribute to development of his society. (National Policy on Education, 2010)

\section{Objectives of Social Studies Education}

1. Create awareness of and sensitivity to man's environment.

2. Influence man's attitudes positively to social, cultural political values and total environment.

3. Enable men to acquire skills for solving societal and environmental problems.

4. Equip men with the basic understanding of the knowledge of the total environment.

5. Encourage voluntary participation in social and civic duties while developing the sense of responsibility.

\section{Role of Social Studies Education in National Development}

Introduction of social studies education into Nigeria schools curriculum can not be over emphasized. This is due to the fact that it infuse in the young a love of the country thereby fostering national unity which is essential to our development as a nation.

It contribute in achieving national objective by relying on its peculiar methodology using inquiry, topical, problematic, project activities and other approaches to expose the children to the pros and cons of various situation, so that they can arrive at their own independent, conclusions based on reasoned judgment.

Social studies education in Nigeria have a special task to perform in transforming Nigeria into a modern state. They include healing the social and political wounds of the past decades, nurturing the most recent hopes in good ethnic group relationship and nationalism, and the engendering constructive reforms to make the nation a just and progressive society. It also helps to foster the desire for self - reliance, national efficiency and national pride.

Moreover, social studies education contribute in the attainment of national goals through citizenship education citizenship education refers to the culture of certain behaviours, knowledge outlooks and values which are found in the culture which the individual participate. A citizen how ever, is one who conforms to certain accepted practices, hold a particular belief that is loyal to certain values, participate in certain activities and conforms to norms which are often local in character.

It contribute in making citizens understand the diversity among the people of Nigeria and further leads them to see the cooperation and later-dependence among them which are among the major elements of nation-building and further plays the role of making the people appreciate and respect the cultural diversity of Nigeria and to realize the need for cooperation, unity and peace in the country (Sheshi T, 2002).

Other roles played by social studies includes:

- The development of National consciousness and commitment as necessary ingredients for nation building.

- The inculcation of social value and skills for active social life

- The development of intellectual skills, knowledge and abilities for better understanding of the immediate and remote environment.

- Developing rational thinking ability for practical social life. 
- Identifying and solving problems using problem solving techniques

- Promoting value awareness and utilization of some values in tackling dynamic problems in the society (Mezieoble, 1994)

\section{Problems that Affect the Attainment of National Development}

- Problems of leadership and followership

- Ethnicity and regionalism

- Problems of crime and insecurity

- Poverty and unemployment

- Negative values and attitudes

- Political instability

- Dependant economy

In lieu of the above, the most recent and disturbing, challenge to national development in Nigeria today is the problem of insecurity which affairs too much for the usual Nigerian good fate. Every Nigerian today lives in fear, not fear of the unknown but the fear of known. The fear that sooner than later a bomb will go off somewhere, likely in a church, a supermarket or a car park and the victim could be either himself or herself. That is the state of the Nation. The fear of the known makes life miserable and incapacitated for the civic life in Nigeria. One can argue however, that fear has always been the stimulus of our civilization. It is fear of the unknown that drives us to creativity and innovation that sustain the human civilization (Weekly Trust, Nov. 17, 2012)

However, even Thomas Hobes argued eloquently that

"It is the desire to escape the fear of the uncertainties in the state of nature that pushed our forebears to the first social compact". (Subrata M. and Sushela R, 2007)

It might then be that this fear of the known will inspire us to a different social compact that will guarantee freedom from fear. This is the state of the union. This degree of insecurity and the inability to effectively overcome it encourage some to talk about early signs of state failure. One of the signs of state failure is the inability of government to provide essential services and protect lives and properties in a sizeable part of its territory. (Weekly Trust, Nov. 17, 2012).

Conclusively, social studies education play's a very vital role in developing rational thinking ability for practical social life, promoting of political literacy and encouraging democratic values and principles for the promotion of functional citizenship. It also enables citizens to develop positive attitudes towards other people and toward citizenship and also to contribute his best towards the welfare of the society and building up of Nigeria.

\section{Suggestions and Recommendations}

- Government should organize public enlightenment campaigns through National Orientation Agency NYSC Orientation Camps, Seminars and workshops on the ways of promoting National Development.

- To enhance social interaction among the citizens, there is need for teaching the basic levels of social studies such as citizenship education, Nigeria as a Nation, Teaching National integration etc.

- Promoting value awareness and tackling dynamic problems in the society by identifying and solving social problems using problem solving techniques. 


\section{References}

Ezegbe, M.O (1994), "Building a Strong United Nigeria Nation Through Social Studies Education in Nigeria". J ournal of Social Studies Review (1)

Federal Republic of Nigeria, National Policy on Education (2010). Lagos, NERDC, Government Press.

Mezieobi, K. (1994) Social Studies Education and Nation Building .Onitsha. Outride Publishers

Ogunbameru, A.K (2006), Man and His Social Environment. Spectrum, Book Ltd.

Sheshi, T.S (2002), Citizenship Education: A panacea for National Consciousness and Sustainable Democracy in Nigeria. A paper presented at the 7th Annual National Conference of Federal College of Education, Kontagora.

Subrata, M. \& Sushila, R. (2007), History of Political Thought. Hall of India, New Delhi.

Weekly Trust, The Challenges for Nation Building in Nigeria. By Sam Amada. Saturday 17th Nov, 2012. 